\title{
The Clinical Importance of Hematological Parameters in Patients with Pulmonary Thromboembolism Diagnosed in the Emergency Department
}

\author{
Acil Serviste Pulmoner Tromboemboli Tanısı Konulan Hastalarda Hematolojik Parametrelerin
} Klinik Önemi

Resmiye Nur Okudan',

Fevzi Yilmaz',

Serkan Yuksel ${ }^{3}$,

Mehmet Akif Karadas ${ }^{4}$, Adeviyye Karaca ${ }^{2}$, Gizem Ayaz ${ }^{2}$, Omer Faruk Karakoyun 5

1- Gebze Fatih State Hospital, Department of Emergency Medicine, Kocaeli /Turkey, 2- Health Sciences University, Antalya Education and Research Hospital; Department of Emergency Medicine, Antalya /Turkey, 3- Kahta State Hospital, Department of Radiology, Adiyaman, Turkey, 4- Baskent University, Alanya Research and Training Center, Department of Emergency Medicine, Alanya, Turkey. 5- Mugla Training and Research Hospital; Department of Emergency Medicine, Mugla /Turkey.

\begin{abstract}
Objective: Acute pulmonary embolism (APE) is a highly fatal acute clinical condition. Herein, we aimed to determine the role of blood parameters in the diagnosis and prognostication of APE.

Material and Method: This study was conducted retrospectively on patients who had been admitted to our hospital's emergency department (ED) and diagnosed with APE. Patients with an RV/LV ratio greater than 0,9 on Computed tomography (CT) and hypotension were grouped as massive APE; patients with stable hemodynamics and an RV/LV ratio greater than 0,9 on CT were defined as submissive APE; and patients with stable hemodynamics and an RV/LV ratio smaller than 0,9 on CT were defined as non-massive APE.

Results: This study enrolled a total of 200 patients, 82 of which were male (41\%) and 118 were female (59\%). APE group had a significantly greater D-dimer level than the control group $(3.559,5 \pm 8.611 .3 \mathrm{ng} / \mathrm{ml} v \mathrm{~s} 266.6 \pm 266.6$ $\mathrm{ng} / \mathrm{ml})(p<0,001)$. Troponin I levels significantly greater in the patient group than control group (53.3 $\pm 90 \mathrm{vs}$ $332.9 \pm 32,9)(p=0.013)$.

Conclusion: Analysis of the hematological parameters between the APE subgroups showed that D-Dimer, leukocyte $(W B C)$, neutrophil, lymphocyte, neutrophil to lymphocyte ratio (NLR), and troponin levels were significantly higher in the massive APE group than the sub-massive and non-massive APE groups.

\section{$\ddot{O Z E T}$}

Amaç: Akut pulmoner emboli (APE), oldukça ölümcül bir akut klinik durumdur. Burada APE'nin tanı ve prognozunda kan parametrelerinin rolünü belirlemeyi amaçladık.

Gereç ve Yöntem: Bu çalışma hastanemizin Acil Servisine (AS) başvuran ve APE tanısı konulan hastalar üzerinde geriye dönük olarak yapldd. Bilgisayarl tomografi (BT)'de RV/LV oranı 0.9'dan büyük ve hipotansiyonu olan hastalar masif APE; BT'de RV / LV oranı 0,9'dan büyük olan ve stabil hemodinamik sahip hastalar submasif APE; BT'de RV / LV oranı 0,9'dan küçük ve hemodinamisi stabil olan hastalar masif olmayan APE olarak sinıflandırıldı.

Bulgular: Bu çalışmaya 82 'si erkek (\%41), $118^{\prime}$ i kadın (\%59) olmak üzere toplam 200 hasta alındl. Hasta ve kontrol grubunun yaş ortalaması sirasıly $65,2 \pm 17,1$ ve 60,5 $\pm 60,5$ yıldl. APE grubu, kontrol grubuna göre anlamlı olarak daha yüksek D-dimer düzeyine sahipti $(3559,5 \pm 8611,3 \mathrm{ng} / \mathrm{ml}$ 'ye karşl 266,6 $266,6 \mathrm{ng} / \mathrm{ml})$

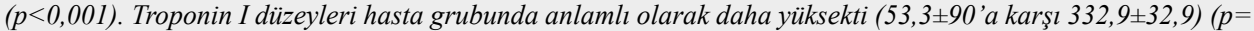
0,013).

Sonuç: Hematolojik parametrelerin APE alt grupları arasındaki analizi, masif APE grubunda D-Dimer, lökosit $(W B C)$, nötrofil, lenfosit, nötrofil / lenfosit oranı (NLR) ve troponin düzeylerinin sub-masif APE ve masif olmayan APE grubuna göre anlamlı olarak daha yüksek olduğunu gösterdi.
\end{abstract}

\section{INTRODUCTION}

Despite the fact that acute pulmonary embilism (APE) may have an asymptomatic course depending on the size and extent of pulmonary embolism, is potentially a lifethreatening event that may culminate into sudden death. The most common source of a pulmonary embolus is the deep veins of the leg (1). Whereas APE is rarely seen in ambulatory individuals free of any risk factor, coagulation abnormalities, intravascular blood stasis, turbulence, and endothelial dysfunction increase its risk (2).

\section{Keywords:}

Acute pulmonary embolism Hematological parameters Emergency Department

Anahtar Kelimeler: Akut Pulmoner Emboli Hematolojik Parametreler Acil Servis

Correspondence: Fevzi Yilmaz, MD, Health Sciences University, Antalya Education and Research Hospital; Department of Emergency Medicine, Antalya /Turkey, Email: fevzi_yilmaz2002@yahoo.com

Cite as: Okudan RN, Yilmaz F, Yuksel S, Karadas MA, Karaca A, Ayaz G, Karakoyun OF. The Clinical Importance of

Hematological Parameters in Patients with Pulmonary Thromboembolism Diagnosed in the Emergency Department. Phnx Med J. 2021;3(3):123-129.

Received: 02.09 .2021 Accepted: 13.09 .2021

Since APE is potentially fatal, it is crucial to diagnose and manage it in a timely manner. Its diagnosis and severity sometimes need to be verified by further tests and studies. Utilization of a number of easy-to-use and simple parameters and indices derived from simple and readily available blood studies has recently attracted attention. These may include cardiovascular biomarkers (brain natriuretic peptide, cardiac troponin I or T, high sensitivity troponin $\mathrm{T}$, heart-type fatty acid-binding protein) or hematological markers derived from blood 


\section{Okudan et al.}

counts (3). It has been shown that most of the parameters are actually related to APE diagnosis, its severity, and its clinical presentation. However, it is unknown which hematological parameter has the greatest diagnostic importance in determining the clinical severity of APE.

Hence, this study aimed to determine hematological parameters that are important for diagnosing APE and determining its severity.

\section{MATERIAL AND METHOD}

\section{Study population}

After it was approved by Health Sciences University Antalya Training and Research Hospital Ethics Committee (05.09.2017-12/14), our study was conducted retrospectively on patients who had been admitted to our hospital's emergency department (ED) and diagnosed with APE. The medical data of the patients were accessed through written medical records of the patients and hospital electronic information management system. A standardized "Study Form" was designed for the study, and after the patients' data were recorded on that form, they were transferred to a digital medium. Demographic information such as age and sex, admission symptoms, comorbidities, vital signs, hemogram and biochemistry tests, treatment regimens, rates of hospital admission/ discharge from ED, and mortality rate were recorded and analyzed in all patients. In addition to APE patients with missing clinical or biochemical data, we also excluded patients with documented heart failure or right and/or left ventricular dysfunction, intracardiac thrombus, pericardial effusion with tamponade, severe pleural effusion, active infection, nephrotic syndrome, acute kidney failure or liver failure, cancer, severe thyroid dysfunction or any other endocrine disorder with hemodynamic disturbances, and any condition deranging hemodynamics, such as severe sepsis or septic shock, major trauma, major surgical procedures, and mechanical ventilation.

Blood samples of all patients were examined using kits

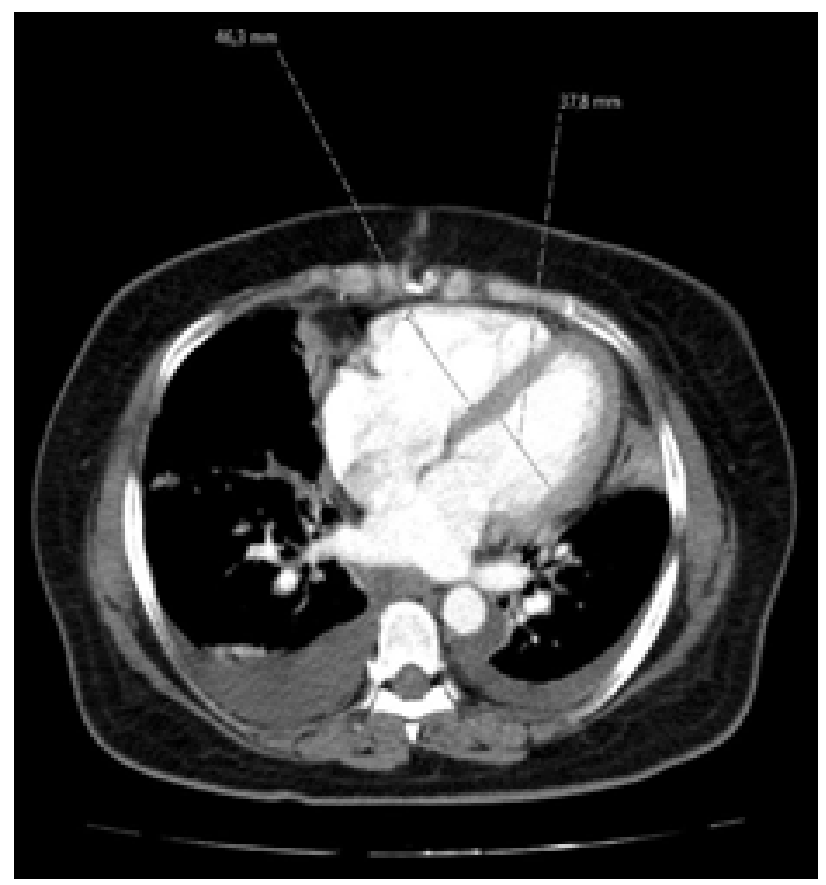

Figure 1: RV/ LV ratio (taken from an actual patient) of the same brand in the same laboratory. Erythrocyte, Platelets (PLT), WBC, and other parameters obtained from full blood count was quantified by a Sysmex XE 2100 optic laser scatter hematology analyzer (Roche Diagnostic, Corp., Indianapolis, IN, USA) using the impedance method; photometric method was used to measure hemoglobin $(\mathrm{Hb})$ level. Serum $\mathrm{C}$-reactive protein (CRP) level was measured with the turbidimetric method (Roche 24 Cobas C 501). Serum D-dimer level was measured with (Alere Triage Meter) device, and troponin I level with (Roche Diagnostics Elecsys 2010) immunoassay analysis device. The normal reference values of our study parameters were as follows: $\mathrm{Hb}(11.7-16 \mathrm{~g} / \mathrm{dL}), \mathrm{WBC}$

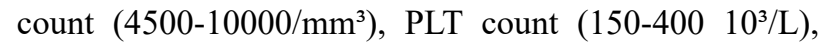
Red Cell Distribution width (RDW) (\%11.6-14.8), CRP (0-5 mg/dL), D-dimer (0-500 ng/mL), troponin I $(<0.01$ $\mathrm{ng} / \mathrm{mL})$.

CT imaging was performed with a multislice CT device using $64 \times 0.5 \mathrm{~mm}$ collimation. Contrast material was injected with an automatic CT injector. All patients were administered $150 \mathrm{ml}$ contrast material at an injection rate of $3.5 \mathrm{ml} / \mathrm{sec}$. Iopromide and iobitridol were used as nonionic contrast material. The images of all patients were evaluated by an expert radiologist.

The patients were divided into two groups by CT pulmonary angiography (CTA) results. Patients who were diagnosed with APE formed the patient group, and patients without APE formed the control group. Patients diagnosed with APE were subdivided into three groups by hemodynamic data and radiological imaging findings. Right ventricle (RV) / left ventricle (LV) ratio was found by measuring and proportioning the short axis-long axis diameters of both ventricles in the axial plane on CT, measuring the widest distance from the interventricular septum to the endocardial line (Figure 1).

According to this measurement and hemodynamic data, patients with an RV/LV ratio greater than 0.9 on $\mathrm{CT}$ and hypotension were grouped as massive APE; patients with stable hemodynamics and an RV/LV ratio greater than 0.9 on CT were defined as submissive APE; and patients with stable hemodynamics and an RV/LV ratio smaller than 0.9 on CT were defined as non-massive APE (1).

\section{Statistical analysis}

All statistical analyses were performed using Statistical Package for Social Sciences (SPSS) for Windows 20 (IBM SPSS Inc., Chicago, IL, USA) software. Normality of distribution of the study variables was tested by Kolmogorov-Smirnov test. Normally distributed quantitative data were expressed as mean $\pm \mathrm{SD}$ and nonnormally distributed quantitative data as median (minmax). Categorical variables were reported as number and percentage. Risk factors of different APE types were determined by ANOVA (posthoc multiple comparisons performed with Bonferroni test). Categorical data were tested using Chi-square test. $\mathrm{p}<0.05$ value was accepted for statistically significant.

\section{RESULTS}

This study enrolled a total of 200 patients, 82 of which were male (41\%) and 118 were female $(59 \%)$. The mean age of the patient and control groups were $65.2 \pm 17.1$ and $60.5 \pm 60.5$ years, respectively. The patient and control 


\section{Phnx Med J. November 2021, Volume 3 No 3}

Table 1: Comparison of the hematological parameters between the patient and control groups

\begin{tabular}{llll}
\hline & Patients & Controls & p \\
\hline Hb & $12.5 \pm 2.2$ & $12 \pm 12$ & 0.047 \\
HTC & $39.1 \pm 8.3$ & $36.6 \pm 36.6$ & 0.019 \\
PLT & $236.4 \pm 106$ & $306.1 \pm 306.1$ & 0.001 \\
WBC & 11540 & 9500 & 0.001 \\
Neutrophil & $9.6 \pm 8.6$ & $8.4 \pm 8.4$ & 0.245 \\
Lymphocyte & $2.7 \pm 3.8$ & $1.9 \pm 1.9$ & 0.071 \\
NLR & 59395 & 71920 & 0.687 \\
MPV & $8.7 \pm 1.5$ & $8.5 \pm 8.5$ & 0.391 \\
RDW & $16 \pm 2.7$ & $15.9 \pm 15.9$ & 0.797 \\
CRP & $79.3 \pm 84.9$ & $64.1 \pm 64.1$ & 0.035 \\
D-Dimer & $3559.5 \pm 8611.3$ & $266.6 \pm 266.6$ & $<0.001$ \\
Troponin & $53.3 \pm 90.3$ & $32.9 \pm 32.9$ & 0.013 \\
PT & $34.2 \pm 10.2$ & $31.7 \pm 31.7$ & 0.005 \\
PTZ & $15.4 \pm 4.8$ & $14.8 \pm 14.8$ & 0.056 \\
INR & $1.3 \pm 0.4$ & $1.3 \pm 1.3$ & 0.112 \\
\hline
\end{tabular}

groups did not significantly differ with respect to mean age $(\mathrm{p}=0.035)$. Sixty percent of the patients were female and $40 \%$ were male while $58 \%$ of the controls were female and $42 \%$ of them were male. The comparison of the sex distribution between the groups with Chi-square test revealed no significant difference $\left(\mathrm{X}^{2}=0.083, \mathrm{sp}=1\right.$, $\mathrm{p}=0.774)$. The comparison between the patient and control groups with respect to the hematological parameters demonstrated significant differences with regard to $\mathrm{Hb}$, hematocrit (HTC), Plt count, CRP, D-Dimer, troponin; However, there was no significant difference regarding WBC, RDW, mean platelet volume (MPV), neutrophil, lymphocyte and NLR (Table 1).

APE group had a significantly greater D-dimer level than the control group $(3559.5 \pm 8611.3 \mathrm{ng} / \mathrm{ml}$ vs $266.6 \pm 266.6$ $\mathrm{ng} / \mathrm{ml})(\mathrm{p}<0,001)$. According to the results of the ROC analysis for D-dimer, a cut-off value of $>600$ had a specificity of $87 \%$, sensitivity of $79 \%$, positive LR of 1.76, negative LR of 0.00 , and AUC of $0.884(p<0.001)$. The comparison of the troponin I levels between the patient and control groups showed that the patient group had a significantly greater troponin I level (53.3 \pm 90 vs $332.9 \pm 32.9)(p=0.013)$ (Table 1). According to the results of the ROC analysis, a cut-off level of $>0.022$ for Troponin I had a specificity of $72.41 \%$, sensitivity of $66.67 \%$, positive LR of 2.42 , negative LR of 0.46 , and AUC of $0.697(p=0.0005)$. Although the lowest NLR level in the patient group was 0.02 and the highest level 45.12, the mean NLR level was 5.94. In the control group, on the other hand, the lowest NLR level was 0.21 the highest NLR level was 63.17 and the mean NLR level was 7.19. According to Spearman's rho correlation analysis, there was no significant difference $(\mathrm{p}>0.05)$ with respect to NLR at a confidence level of $\mathrm{p}=0.05$. The whole collection of the significantly different hematological parameters between the patient and control groups found in the ROC analysis were presented in figure 2 .

The patients were categorized into three subgroups by hemodynamic data and radiological images, which identified 22 patients with massive APE, 49 patients with submassive APE, and 29 patients with non-massive APE. According to the statistical analysis with $95 \%$ confidence interval, mean, and standard deviation values, the massive subgroup showed significant differences from the submassive and non-massive groups in respect to systolic blood pressure (SBP), diastolic blood pressure (DBP), respiratory rate $(\mathrm{RR})$, oxygen saturation (SO2), pulse rate, fever, Right ventricular diameter, Left ventricular diameter, and Right ventricle/Left ventricle ratio $(\mathrm{p}<0,05)$ (Table 2).

Table 3 shows the laboratory parameters pertaining to the APE subgroups. The massive APE subgroup had significantly higher levels of D-dimer, WBC, neutrophil, lymphocyte, NLR, and Troponin compared with the other APE subgroups. The subgroups, however, were similar in

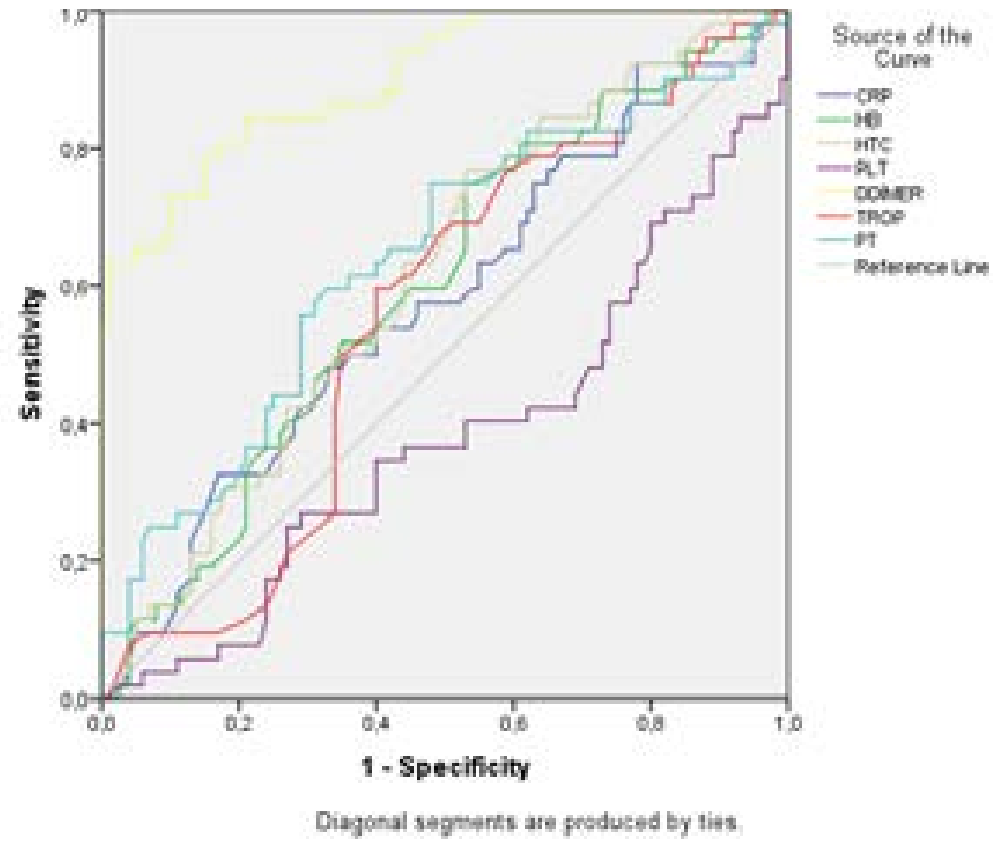

Figure 2: ROC analysis for Hb, Htc, Plt, CRP, D-dimer, and Troponin I 
Okudan et al.

Table 2: Comparison of massive, sub-massive and non-massive APE groups regarding vital parameters and radiological signs.

\begin{tabular}{|c|c|c|c|c|c|c|c|}
\hline & & \multirow[t]{2}{*}{$\mathbf{n}$} & \multirow[t]{2}{*}{ Mean } & \multirow[t]{2}{*}{ Std. Deviation } & \multicolumn{2}{|c|}{$\begin{array}{c}\text { 95\% Confidence Interval } \\
\text { for Mean }\end{array}$} & \multirow[b]{2}{*}{$\mathrm{p}$} \\
\hline & & & & & $\begin{array}{l}\text { Lower } \\
\text { Bound }\end{array}$ & $\begin{array}{l}\text { Upper } \\
\text { Bound }\end{array}$ & \\
\hline \multirow{3}{*}{ SBP } & Massive & 22 & 96.075 & 17.025 & 88.50 & 103.59 & \multirow{3}{*}{.000} \\
\hline & Sub-massive & 49 & 114.78 & 19.122 & 109.28 & 120.27 & \\
\hline & Non-massive & 29 & 121.55 & 24.589 & 112.20 & 130.90 & \\
\hline \multirow{3}{*}{ DBP } & Massive & 22 & 56.32 & 12.830 & 50.63 & 62.01 & \multirow{3}{*}{.000} \\
\hline & Sub-massive & 49 & 68.69 & 11.406 & 65.42 & 71.97 & \\
\hline & Non-massive & 29 & 70.17 & 13.538 & 65.02 & 75.32 & \\
\hline \multirow{3}{*}{ Pulse rate } & Massive & 22 & 108.14 & 28.663 & 95.43 & 120.84 & \multirow{3}{*}{0.031} \\
\hline & Sub-massive & 49 & 104.27 & 16.485 & 99.53 & 109.00 & \\
\hline & Non-massive & 29 & 95.41 & 14.234 & 90.00 & 100.83 & \\
\hline \multirow{3}{*}{$\mathbf{R R}$} & Massive & 22 & 19.86 & 2.817 & 18.61 & 21.11 & \multirow{3}{*}{.000} \\
\hline & Sub-massive & 49 & 17.47 & 2.829 & 16.66 & 18.28 & \\
\hline & Non-massive & 29 & 16.24 & 1.766 & 15.57 & 16.91 & \\
\hline \multirow{3}{*}{ SO2 } & Massive & 22 & 86.23 & 7.752 & 82.79 & 89.66 & \multirow{3}{*}{.000} \\
\hline & Sub-massive & 49 & 93.12 & 4.371 & 91.87 & 94.38 & \\
\hline & Non-massive & 29 & 94.72 & 3.981 & 93.21 & 96.24 & \\
\hline \multirow{3}{*}{ RV diameter } & Massive & 22 & 45.586 & 8.1952 & 41.953 & 49.220 & \multirow{3}{*}{.000} \\
\hline & Sub-massive & 49 & 40.235 & 5.6503 & 38.612 & 41.858 & \\
\hline & Non-massive & 29 & 34.186 & 7.3227 & 31.401 & 36.972 & \\
\hline \multirow{3}{*}{ LV diameter } & Massive & 22 & 34.714 & 7.6884 & 31.305 & 38.122 & \multirow{3}{*}{.000} \\
\hline & Sub-massive & 49 & 37.118 & 4.6740 & 35.776 & 38.461 & \\
\hline & Non-massive & 29 & 42.597 & 7.2789 & 39.828 & 45.365 & \\
\hline \multirow{3}{*}{$\mathrm{RV} / \mathrm{LV}$ ratio } & Massive & 22 & 1.3672 & .37486 & 1.2010 & 1.5334 & \multirow{3}{*}{.000} \\
\hline & Sub-massive & 49 & 1.1011 & .12821 & 1.0643 & 1.1379 & \\
\hline & Non-massive & 29 & .8013 & .08232 & .7699 & .8326 & \\
\hline
\end{tabular}

terms of $\mathrm{Hb}$, Htc, Plt, RDW, MPV, and CRP.

According to the analysis results, all patients with massive APE diagnosed in the ED were treated as in-patients while 22 patients with sub-massive APE and 19 patients with non-massive APE were treated in the ED and discharged afterwards. Of 41 hospitalized patients, 9 had massive APE, nine had non-massive APE, and 23 had sub-massive APE. Six of eight patients admitted to the intensive care unit had massive APE, one had sub-massive APE, and one had non-massive APE. Five patients with massive APE died. A review of the treatment regimens administered to the patients showed that 18 patients with massive APE received thrombolytic therapy and four patients received anticoagulant therapy. Forty-nine patients with sub-massive APE were administered anticoagulant therapy while 29 patients with non-massive APE received symptomatic treatment.

\section{DISCUSSION}

Pulmonary embolism constitutes a frequent cause of ED admissions (4). Since APE is a highly morbid and potentially fatal acute emergency condition and its presence and severity should be rapidly determined, worldwide efforts are ongoing to find simple and readily available parameters or markers to accomplish this goal (5). Herein, we investigated the collective role of blood parameters in APE, which have been previously studied for the same purpose separately. The incidence of APE increases with age, with the risk doubling for each 10year period after the age of 50. Keller et al. found a mean age of $68.5 \pm 15.3$ in 182 APE patients (6). In our study, the mean age was $65.2 \pm 17.1$ years in the patient group and $60.5 \pm 60.5$ years in the control group. The statistical comparison of the mean age of both groups showed no significant difference $(\mathrm{p}=0.774)$.

There is no definitive diagnostic laboratory marker in APE; however, among available laboratory markers, the most valuable one is plasma D-dimer, which can increase up to 8 times in cases of APE. The reported sensitivity of D-dimer levels above $500 \mathrm{ng} / \mathrm{ml}$ to diagnose APE is 97-100\% (7). Huang et al. compared D-dimer levels between patients with APE and the control group, and found significantly higher D-dimer levels in the APE group (3.860 ng/ml vs $583 \mathrm{ng} / \mathrm{ml}, \mathrm{p}<0.01$ ) (8). Our study demonstrated a significantly greater $\mathrm{D}$-dimer level in the APE group (3559.5 ng/ml vs $266.6 \mathrm{ng} / \mathrm{ml}, \mathrm{p}<0.001)$. In addition, D-dimer in our study had a sensitivity of $79 \%$ 


\section{Phnx Med J. November 2021, Volume 3 No 3}

Table 3: Laboratory findings of study population according to subtype of APE

\begin{tabular}{|c|c|c|c|c|c|c|c|}
\hline \multirow[t]{2}{*}{$\begin{array}{l}\text { Hematological } \\
\text { Parameters }\end{array}$} & & \multirow[t]{2}{*}{$\mathbf{n}$} & \multirow[t]{2}{*}{ Mean } & \multirow[t]{2}{*}{$\begin{array}{l}\text { Std. Devia- } \\
\text { tion }\end{array}$} & \multicolumn{2}{|c|}{$\begin{array}{c}\text { 95\% Confidence Interval } \\
\text { for Mean }\end{array}$} & \multirow[b]{2}{*}{$\mathrm{p}$} \\
\hline & & & & & $\begin{array}{l}\text { Lower } \\
\text { Bound }\end{array}$ & $\begin{array}{l}\text { Upper } \\
\text { Bound }\end{array}$ & \\
\hline \multirow{3}{*}{$\mathbf{H b}$} & Massive & 22 & 12564 & 2.0084 & 11.673 & 13.454 & \\
\hline & Sub-massive & 49 & 12690 & 2.3026 & 12.028 & 13.351 & 0.718 \\
\hline & Non-massive & 29 & 12255 & 2.2822 & 11.387 & 13.123 & \\
\hline \multirow{3}{*}{ HTC } & Massive & 22 & 39.1 & 5.6353 & 8.618 & 19.284 & \\
\hline & Sub-massive & 49 & 36.6 & 7.3595 & 36.7901 & 39.013 & 0.720 \\
\hline & Non-massive & 29 & 37.6 & 8.3284 & 36.668 & 43.185 & \\
\hline \multirow{3}{*}{ PLT } & Massive & 22 & 234180 & 122495 & 179.87 & 288.49 & \\
\hline & Sub-massive & 49 & 236240 & 87660 & 211.07 & 261.42 & 0.878 \\
\hline & Non-massive & 29 & 238390 & 123581 & 191.38 & 285.39 & \\
\hline \multirow{3}{*}{ CRP } & Massive & 22 & 73.18 & 66.967 & 43.49 & 102.87 & \\
\hline & Sub-massive & 49 & 69.86 & 88.603 & 44.41 & 95.31 & 0.109 \\
\hline & Non-massive & 29 & 99.86 & 89.802 & 65.70 & 134.02 & \\
\hline \multirow{3}{*}{ D-dimer } & Massive & 22 & 9871.00 & 15051.906 & 3.197 .36 & 16.544 .64 & \\
\hline & Sub-massive & 49 & 2261.82 & 5412.672 & 707.12 & 3.816 .52 & .000 \\
\hline & Non-massive & 29 & 964.24 & 908.167 & 618.79 & 1309..69 & \\
\hline \multirow{3}{*}{ Troponin } & Massive & 22 & 64.73 & 67.254 & 34.91 & 94.55 & \\
\hline & Sub-massive & 49 & 60.80 & 111.561 & 28.75 & 92.84 & 0.002 \\
\hline & Non-massive & 29 & 31.93 & 58.531 & 9.67 & 54.19 & \\
\hline \multirow{3}{*}{ WBC } & Massive & 22 & 14184.6 & 5935.9 & 7.718 & 18.184 & \\
\hline & Sub-massive & 49 & 9395.7 & 7159.1 & 36.901 & 41.013 & $<.001$ \\
\hline & Non-massive & 29 & 9286 & 11328.7 & 35.567 & 44.185 & \\
\hline \multirow{3}{*}{ RDW } & Massive & 22 & 15.282 & 1.8679 & 14.454 & 16.110 & \\
\hline & Sub-massive & 49 & 16.096 & 2.6454 & 15.336 & 16.856 & 0.620 \\
\hline & Non-massive & 29 & 16.331 & 3.3918 & 15.041 & 17.621 & \\
\hline \multirow{3}{*}{ MPV } & Massive & 22 & 8.65 & 1.541 & 7.96 & 9.33 & \\
\hline & Sub-massive & 49 & 8.61 & 1.191 & 8.27 & 8.96 & 0.926 \\
\hline & Non-massive & 29 & 8.87 & 1.980 & 8.11 & 9.62 & \\
\hline \multirow{3}{*}{ Neutrophil } & Massive & 22 & 14541 & 15367.8 & 7.727 & 21.355 & \\
\hline & Sub-massive & 49 & 8353 & 4954.6 & 6.930 & 9.776 & 0.015 \\
\hline & Non-massive & 29 & 7803 & 4289.6 & 6.172 & 9.435 & \\
\hline \multirow{3}{*}{ Lymphocyte } & Massive & 22 & 3.13 & 2.018 & 2.23 & 4.02 & \\
\hline & Sub-massive & 49 & 2.19 & 1.624 & 1.72 & 2.66 & 0.050 \\
\hline & Non-massive & 29 & 3.34 & 6.584 & .84 & 5.85 & \\
\hline \multirow{3}{*}{ NLR } & Massive & 22 & 7.6 & .66019 & 1.7 & 30.4 & \\
\hline & Sub-massive & 49 & 3.1 & .54834 & 0.8 & 10.1 & 0.046 \\
\hline & Non-massive & 29 & 3.0 & .55430 & 0.9 & 8.9 & \\
\hline
\end{tabular}

and a specificity of $87 \%$ for massive APE, which were generally in accordance with the literature data.

Although troponin level does not confer a diagnostic importance in APE, studies have linked higher troponin levels to increased mortality (9). In a study reported by Çelik et al., troponin I level were significantly higher in patients with APE (10). In accordance with the literature data, our study found a higher troponin level in the patient group $(53.3 \mathrm{ng} / \mathrm{mL}$ vs $32.9 \mathrm{ng} / \mathrm{mL})$. According to the results of a ROC analysis performed for this parameter, an elevated troponin level had a specificity of $61 \%$ and a sensitivity of $60 \%$ for APE. Although elevated troponin level alone is not used for diagnosis or exclusion of APE, it appears to be important for determining disease severity and predicting its prognosis.

CRP is an acute-phase reactant that is a marker of inflammation in the body. CRP is mainly synthesized in the liver, but it is also produced by adipose tissue, 


\section{Okudan et al.}

endothelial cells, smooth muscle cells, and similar vascular wall cells (11). CRP can be elevated by many conditions such as acute and chronic inflammation, tissue necrosis, infections, tumors, post-surgical period, and obesity (12). Çelik et al. reported a significantly higher CRP level in patients with APE compared to controls (10). However, according to the study by Huang et al., patients with and without APE showed no significant difference in respect to CRP level (8). Our study revealed a higher CRP level in the patient group compared with the controls $(79.3 \mathrm{mg} / \mathrm{L}$ vs $64.1 \mathrm{mg} / \mathrm{L}$ ). Although the literature data regarding the relationship between CRP and APE are heterogeneous, it can be argued based on our study results that CRP level alone cannot be used to diagnose APE, but it is one of the supportive laboratory parameters weakly related to APE. Although a specific relationship between $\mathrm{Hb}$ and $\mathrm{Htc}$ levels and APE has yet to be explained, they affect a patient's condition at all stages of diagnosis, treatment, and follow-up. A study by Talay and colleagues reported no significant difference between the APE and control groups regarding $\mathrm{Hb}$ and $\mathrm{Htc}$ levels (13). The $\mathrm{Hb}$ level of our patient and control groups were 12.5 and 12 respectively. The statistical analysis found a $\mathrm{p}$-value of 0.047. The mean Htc level was 39.1 in the patients and 36.6 in the controls, with a p-value of 0.19. Accordingly, our study indicated a significant relationship between $\mathrm{Hb}$ and Htc levels and APE. However, these parameters were not correlated to disease severity.

While many studies on the platelet count in the diagnosis and prognosis of APE have reported a significantly lower platelet count in patients with APE, some others failed to demonstrate any significant difference. Huang et al. reported that the patients diagnosed with APE and the control group showed no significant difference with respect to thrombocyte count (8). In our study, the patient group had a mean thrombocyte count of 236.4, and the control group of 306.1 , with the two groups having differed significantly with regard to this parameter $(\mathrm{p}<0.001)$. According to the results of a ROC analysis performed for thrombocyte count, the latter had a specificity of $59 \%$, a sensitivity of $69 \%$, and a cut-off value of 252 . Our results suggest that although thrombocyte count cannot diagnose PTE, it can be used as an ancillary diagnostic parameter. RDW is a parameter found in the routine hemogram, which shows erythrocyte heterogeneity. Reflecting the morphology of erythrocytes, RDW is widely used for the differential diagnosis of different types of anemia. However, systemic inflammation, nutritional disorders, ineffective erythropoiesis, and bone marrow dysfunction may also cause RDW increase (14). There are literature studies indicating increased RDW level in cardiovascular diseases, cancer, diabetes, liver and kidney failure, and sepsis (15). Barış et al. reported that RDW level showed a significant increase in patients with APE compared with the control group, with the length of hospital stay and mortality rate having been increased significantly in patients with increased RDW levels (16). Our study found a mean RDW level of 16 in the patient group and 15.9 in the control group, with the two groups being similar in respect to RDW level.

MPV is a parameter measured by automatic hemogram analyzers in routine hemograms, and it is one of the principal indicators of platelet reactivity (17). Based on the assumption that larger thrombocytes are more thrombogenic, it reflects platelet activation by representing their mean volume. So far, MPV has been studied in various different disorders, where it has been gained prominence as an independent risk factor $(18,19)$. Elevated MPV has been strongly associated with acute deep venous thrombosis (DVT) and APE in recent studies (13). Yardan et al. reported that MPV level was significantly greater in patients with APE and right ventricle dysfunction (20). We found no significant difference between the MPV levels of our patient and control groups.

Leukocytes have been implicated in the pathophysiology of venous thrombosis due to their disruptive effects on vascular endothelium. Hence, leukocytosis has been linked to increased rates of venous thromboembolism, major hemorrhage, and death (21). Afzal et al. (22) were the first researchers that pointed to an increased WBC count in APE. As an advance in this field, NLR in peripheral blood has been recently focused on as an inflammatory marker that is superior than the more simple WBC count. It is believed that the ratio of neutrophils to lymphocytes is increased in the presence of systemic inflammation. Kayrak et al. (23) in a study comprising 359 APE patients, found that NLR had a prognostic value for early mortality. In line with literature reports, our study also revealed a significant difference between WBC and NLR levels of the patient and control groups $(\mathrm{p}<0,05)$.

\section{CONCLUSION}

The relationship between the clinical severity of APE and blood parameters were studied in the present study. Our study demonstrated significant differences between the patient and control groups with regard to the blood levels of Hb, HTC, PLT, CRP, D-Dimer, Troponin and PT, but not regarding WBC, RDW, MPV, neutrophil, lymphocyte, and NLR levels. However, an analysis of the hematological parameters between the three APE subgroups, namely massive APE, sub-massive APE, and non-massive APE, showed that D-Dimer, WBC, neutrophil, lymphocyte, NLR, and Troponin levels were significantly higher in the massive APE group than the sub-massive and nonmassive APE groups.

Conflict Interest: No conflict of interest was declared by the authors

Ethics: This study was approved by Health Sciences University Antalya Training and Research Hospital Ethics Committee (05.09.2017-12/14),

Acknowledgments: We are deeply indebted to all our colleagues for their understanding and cooperation.

Financial Disclosure: The authors declare that the research did not receive specific funding. 


\section{Phnx Med J. November 2021, Volume 3 No 3}

\section{REFERENCES}

1. Ates H, Ates I, Kundi H, Yilmaz FM. Diagnostic validity of hematologic parameters in evaluation of massive pulmonary embolism. J Clin Lab Anal. 2017;31(5): e22072.

2. Howard L. Acute pulmonary embolism. Clin Med (Lond). 2019;19(3):243-247.

3. Konstantinides S, Goldhaber SZ. Pulmonary embolism: Risk assessment and management. Eur Heart J. 2012;33:3014-3022.

4. Konstantinides SV, Torbicki A, Agnelli G, et al. 2014 ESC guidelines on the diagnosis and management of acute pulmonary embolism. Eur Heart J. 2014;35(43):3033-69, 3069a-3069k.

5. Ates H, Ates I, Bozkurt B, Celik HT, Ozol D, Yldrm Z. What is the most reliable marker in the differential diagnosis of pulmonary embolism and community-acquired pneumonia? Blood Coagul Fibrinolysis. 2016;27:252-258

6. Keller K, Beule J, Balzer JO, Dippold W. Typical symptoms for prediction of outcome and risk stratification in acute pulmonary embolism. International angiology: a journal of the International Union of Angiology. 2016;35(2):184-191.

7. De Moerloose P, Desmarais S, Bounameaux H, Reber G, Perrier A, Dupuy G, et al. Contribution of a new, rapid, individual and quantitative automated D-dimer ELISA to Exclude pulmonary embolism. Thromb Haemost. 1996;75(1):11-13.

8. Huang J, Chen Y, Cai Z, Chen P. Diagnostic value of platelet indexes for pulmonary embolism, American Journal of Emergency Medicine. 2015;33(6):760-763

9. Meyer M, Fink C, Roeger S, Apfaltrer P, Haghi D, Kaminski WE, et al. Benefit of combining quantitative cardiac CT parameters with troponin I for predicting right ventricular dysfunction and adverse clinical events in patients with acute pulmonary embolism. Eur J Radiol. 2012;81(11):32943299

10. Celik A, Ozcan T, Gundes A, Topuz M, Pektas I, Yesile E, et al. Usefulness of admission hematologic parameters as diagnostic tools in acute pulmonary embolism. Kaohsiung Journal of Medical Sciences. 2015;31:145-149.

11. McPherson RA, Matthew R. Pincus MR. Henry's Clinical Diagnosis and Management by Laboratory Methods. 22nd ed. Elsevier Saunders: Philadelphia; 2011. pp. 254-255.

12. Burris CA, Ash wood ER, Burns DE. Tietz Textbook of Clinical Chemistry and Molecular Diagnostics. 4th ed. St. Louis: Elsevier Saunders; 2006. pp. $962-967$.

13. Talay F, Ocak T, Alcelik A, Erkuran K, Akkaya A, Duran A, et al. The new diagnostic marker for acute pulmonary embolism in emergency department; mean platelet volume. African Health sciences. 2014;14(1):94-9.

14. Salvagno GL, Sanchis-Gomar F, Picanza A, Lippi G. Red blood cell distribution width: A simple parameter with multiple clinical applications. Crit Rev Clin Lab Sci. 2015;52:86-105.

15. Bucciarelli P, Maino A, Felicetta I, Abbattista M, Passamonti SM, Artoni A, et al. Association between red cell distribution width and risk of venous thromboembolism. Thromb Res. 2015;136:590-594.

16. Argun Barış S, Önyılmaz T, Kuşlu Uçar E, Çiftçi T, Başyiğit İ, Boyacı H, et al. The Role of The RDW Level on Characteristics of Hospitalization and Mortality Rates in Patients with Pulmonary Thromboembolism. Kocaeli Medical J. 2016;5;3:18-24.

17. Gawaz M, Langer H, May AE. Platelets in inflammation and atherogenesis. J Clin Invest. 2005;115(12):3378-3384.

18. Erdogan D, Tayyar S, Icli A, Uysal BA, Varol E, Ozaydin M, et al. Elevated mean platelet volume is associated with impaired coronary microvascular function in patients with idiopathic dilated cardiomyopathy. Platelets. 2012;23(3):177-183.

19. Bath P, Algert C, Chapman N, Neal B. Association of mean platelet volume with risk of stroke among 3134 individuals with history of cerebrovascular disease. Stroke. 2004;35(3):622-626.

20. Yardan T, Meric M, Kati,C Celenk Y, Atici AG. Mean platelet volume and mean platelet volume/platelet count ratio in risk stratification of pulmonary embolism. Medicina (Kaunas). 2016;52(2):110-115.

21. Jo JY, Lee MY, Lee JV, Rho BH, Choi W. Leukocytes and systemic inflammatory response syndrome as prognostic factors in pulmonary embolism patients. BMC Pulm Med. 2013;13:74-81.

22. Afzal A, Noor HA, Gill SA, Brawner C, Stein PD. Leukocytosis in acute pulmonary embolism. Chest. 1999;115(5):1329-1332.

23. Kayrak M, Erdoğan HI, Solak Y, Akilli H, Gül EE, Yildirim O. Prognostic value of neutrophil to lymphocyte ratio in patients with acute pulmonary embolism: a restrospective study. Heart Lung Circ. 2014;23:56-62. 